\title{
Disclosure of non-financial information on strategy in South African annual reports
}

\author{
Nirupa Padia \\ School of Accountancy, Faculty of Commerce, Law and Management, University of the Witwatersrand, \\ Johannesburg, South Africa. E-mail: nirupa.padia@wits.ac.za.Tel: 083660 5805, 0865535068.
}

Accepted 28 August, 2012

\begin{abstract}
This study examined the extent to which South African companies disclosed non-financial information in their annual reports in 2005 and 2008. To this end, a sample of one hundred Johannesburg Securities Exchange (JSE) listed companies was selected in 2005 from the Financial Mail list of the top two hundred companies listed on the basis of their turnover in Financial Mail (2005). The same sample was used in 2008, but in the interim had decreased to eighty-eight (owing to mergers and acquisitions). The aim of the study was to evaluate the correlation between the amount of non-financial information disclosed in the annual reports of the selected companies for 2005 and for 2008. The study also focused on assessing the impact of non-financial information on the Financial Mail ranking for the same sample in 2008 in relation to the amount of non-financial information disclosed. The investigation was carried out by scoring the amount of non-financial information disclosed using the ten disclosure criteria used in a Dutch study of Santema and Van De Ritj (2001) and two additional criteria included specifically for the South African context: black economic empowerment (BEE); and human immunodeficiency virus (HIV) or acquired immunodeficiency syndrome (AIDS) in Padia and Yasseen (2011).
\end{abstract}

Key words: Annual reports, strategy, South Africa, disclosure of non-financial information.

\section{INTRODUCTION}

The nature of business and corporate governance has evolved over the past two decades (Gray et al., 1995a). The integration and growing globalisation of the securities market has resulted in an increased focus on the disclosure of non-financial information (Bukh et al., 2005). Non-financial information refers to a company's mission, vision and corporate strategy (Bowman, 1978; Kohut and Segars, 1992; Santema and Van De Ritj, 2001). It is maintained that increased levels of non-financial information disclosure reduce the possibility of information asymmetries between a firm and its existing and potential shareholders (Luez and Verrecchia, 2000). Moreover, financial analysts use such information to provide earnings forecasts and make buy/sell recommendations (Lang and Lundholm, 1996).

Companies use a variety of communication sources to disclose non-financial information. These sources include annual reports, press releases, and formal and informal meetings with financial analysts (Gray et al., 1995b). Annual reports have become an influential instrument for communicating non-financial information because they reveal more about a company's strategy than most managers are prepared to give (Bowman, 1978; Kohut and Segars, 1992; Santema et al., 2005a, b).

Recently, Padia and Yasseen (2011) conducted a study which focused on strategy disclosure in the annual reports of JSE-listed South African companies. The aim of the study was to examine the extent to which companies disclose their strategies in their annual reports. A sample of one hundred companies listed on the JSE was selected from the Financial Mail list of the top two hundred companies based on turnover (Financial Mail, 2005). These rankings, which were used in the Padia and Yasseen (2011) study, have been replicated in this study. The Financial Mail provides these rankings every year and consequently highlights the top 200 JSE- 
Table 1. Strategy criteria selected (adapted from Santema and Van De Ritj, 2001).

\begin{tabular}{ll}
\hline 01 & Mission: What does the company want to be? \\
02 & Goal: What general controls does the company have? \\
03 & Objectives: What concrete quantitative goals does the company have? \\
04 & Corporate strategy: What is the corporate strategy of the company? \\
05 & Consistency: Is the corporate strategy in line with the statements on strategy in previous reports? \\
06 & Monitoring: Are the goals and the objectives monitored? \\
07 & Business unit goals: What are the goals of the business units? \\
08 & Business unit strategies: What are the strategies of the business units? \\
09 & Action plans (ex-post): What actions have been executed in the past year in relation to the strategy? \\
10 & Actions plans (ex-ante): What action plans are to be executed in the next year in relation to the strategy? \\
\hline
\end{tabular}

Table 2. Additional strategy criteria (adapted from Padia and Yasseen, 2011).

11 HIV/AIDS: What is the company's strategy with regard to HIVIAIDS?

12 Black economic empowerment: What BEE-related strategies are in place?

listed companies based on their annual turnover. This method was chosen owing to its consistency.

The top 200 companies were analysed according to a set of twelve criteria, which included ten criteria used in the study by Santema and Van de Ritj (2001) (Table 1), and two additional criteria (black economic empowerment [BEE] and human immunodeficiency virus/acquired immune deficiency syndrome [HIV/AIDS]), which were particularly relevant to the South African context of the study (Table 2). A comparison of the annual reports of 2005 and 2008 was undertaken to establish any effect that a change in the disclosure of non-financial information might have had on strategy.

A statistical analysis of the results revealed that the twelve strategy variables could be grouped into categories that focused on the strategy variables of mission, objective and goals. The rating ranged from $23 \%$, where there was very little or no disclosure, to $73 \%$, which meant that companies made sufficient corporate disclosure. In comparison to the Dutch study, the disclosure on mission and vision was slightly higher, as the Dutch study scored a low 15\% (Padia and Yasseen, 2011).

The two additional variables, HIV/AIDS and BEE, which were included in order to make the study relevant to the South African context, obtained the lowest scores in comparison to the ten other strategic criteria (Padia and Yasseen, 2011). Padia and Yasseen (2011) state that the reason for the low scores is that the South African economy is still in transition; accordingly, companies made minimal disclosure about strategy on HIV/AIDS. Overall results indicate that South African listed firms disclosed more about their corporate strategy than the Dutch listed firms. Although non-financial information disclosure was voluntary and not required by law, JSE and Dutch listed companies might have been expected to disclose more non-financial information in light of the fact that more emphasis has been placed on this in recent times. However, a number of factors had an impact on the overall results, namely, the time difference between the two studies, changes in corporate governance, alterations to company legislation, and modifications to the way firms conducted their operations (Padia and Yasseen, 2011).

\section{LITERATURE REVIEW}

The conceptual framework for presenting and preparing financial statements has changed over the past two decades (Gray et al., 1995b). Prior to 1999, non-financial information disclosed in annual reports was founded on a merit-based philosophy (Cheng and Courtenay, 2004). In addition, the disclosure of non-financial information was accorded a lower priority compared to traditional financial information, with traditional financial information referring to numerical or quantitative disclosure in the annual reports (Gibbins et al., 1990).

The growing globalisation of the securities market and the changing needs of shareholders have enhanced the importance of non-financial information disclosure. Accordingly, the disclosure of non-financial information plays an important role in the evaluation of a firm's earnings forecast (Bukh et al., 2005). Therefore, firms with more voluntary non-financial disclosure attract more financial analysis and potential investors. Increased disclosure of nonfinancial information also improves the accuracy of market expectations, reduces information asymmetries between the firm and its shareholders and limits market surprises (Lang and Lundholm, 1996; Baker and Mezzetti, 2001; Collett and Hrasky, 2005; Petersen and Plenborg, 2006; Francis et al., 2007).

Research on corporate disclosure policy is silent on who in an organisation is accountable and responsible for the decisions made about non-financial disclosure, as well as on what the impact 
of external disclosure rules is on the decisions made regarding nonfinancial information disclosure (Gibbins et al., 1990). Users of financial reports require more transparency and accountability regarding corporate governance and corporate disclosure (Beattie et al., 2004). Such users include shareholders, creditors, suppliers, employees and other interested stakeholders (Miller, 1990).

"Business is not just about making sound investment decisions, taking management risks, and dealing with economic uncertainties" (Aziz, 2002). Accordingly, Aziz (2002) equates corporate governance to personal integrity and emphasises the importance of being accountable when making decisions about non-financial disclosure. $\mathrm{He}$ stresses the importance of corporate governance and the disclosure of non-financial information in a company's annual report (Aziz, 2002).

Corporate governance was instituted in order to protect stakeholders, creditors, suppliers and employees, and is considered an essential disclosure requirement for all listed companies (IOD, 2009). In the past, managers put their own interests before those of the firm and its stakeholders, creditors, suppliers and employees (Santema and Van de Ritj, 2001; IOD, 2009). Prominent examples here include Enron, World Com and Tyco in the United States of America (USA), HIH in Australia, as well as Regal Treasury (Bank), Health and Racket (Leisure Net) and Krion in South Africa. Stakeholders lost billions of rand because these companies acted recklessly and conducted their business fraudulently (IOD, 2009).

The King Code of Corporate Governance serves as a guide for the disclosure of non-financial information. The Code specifies that companies should act in the best interests of their stakeholders. In South Africa, companies are required by law to provide financial and non-financial information that is transparent, accurate, relevant and comparable. Moreover, companies must act with due care and skill and not in a reckless or fraudulent manner (Santema and Van De Ritj, 2001; IOD, 2009).

Several reform initiatives have taken place over the years to provide guiding principles for governance practices. For example, the Cadbury, Greenbury, Hempel and Higgs reports in the United Kingdom, the Bosch Commission in Australia and the Blue Ribbon Commissions in the United States, as well as the Sarbanes-Oxley Act which was adopted by the United States of America in 2002. The Sarbanes-Oxley Act provides a statutory basis for corporate governance; it is a rules-based approach that results in legal sanctions for non-compliance (IOD, 2009).

Since 1994, South Africa has adopted the guidelines of the King Commission on Corporate Governance, which is referred to as the King I Report. In 2002, the King II Report was adopted; this report emphasised the importance of stakeholders and a company's sustainability report, which raises issues regarding the disclosure of non-financial information. Subsequently, in 2009, the King III Report was published, which addresses the anticipated new Companies Act as well as changes in international governance trends (IOD, 2009). King III has subsequently resulted in a greater emphasis on non-financial disclosure.

Compared with the two earlier reports, King I (1994) and King II (2002) (IOD, 2009), King III encompasses the following:

1. The majority of a company's directors should be non-executive directors, who are independent of all company operations. In addition, an independent non-executive chairperson should chair the board of directors.

2. Shareholders are responsible for approving the remuneration policy, which must be published. All board members should receive a fair remuneration, including payouts on resignation.

3. Risk management is considered to be inseparable from company strategy and business processes.

4. Compliance with laws, regulations, rules and standards is not regarded as a function of the board.

5. Managing stakeholders' relationships is not part of sustainability reporting.

6. For the first time, as a result of the new Companies Act, the King Report includes mergers, acquisitions and take-overs.

7. King III applies to all entities: their incorporation or establishment, and even "SOC Limited", as defined by the Public Finance Management Act and the Municipal Finance Management Act.

\section{RESEARCH QUESTION AND METHODOLOGY}

Managers are generally given considerable room to manoeuvre in terms of the quality and quantity of disclosure on company-specific governance practices, even where disclosure requirements already exist (Labelle, 2002, in Collett and Hrasky, 2005). Wallace and Naser (1995) maintain that non-financial disclosure in an annual report cannot be measured accurately, even though the quality of the information disclosed can be measured in terms of its accuracy, reliability, relevance and comparability (Wallace and Naser, 1995; Santema and Van de Rijt, 2001; Stanton and Stanton, 2002).

There are various ways in which the quality of non-financial information disclosure has been measured in the past (Tasker, 1998). For example, Lang and Lundholm (1993, 1996), Healy et al. (1998) and Botosan (1997) used analyst ranking to measure the quality of non-financial information disclosure. Tasker (1998), on the other hand, created a relative disclosure index by investigating the disclosure attributes of the individual annual reports filed by smaller firms. The objective of this study was to:

1. Evaluate the correlation between the amount of non-financial information disclosed in the annual reports of South African JSElisted companies in 2005 and 2008.

2. Assess the impact that the amount of non-financial information disclosed has had on the Financial Mail ranking for the same sample in 2008.

The extent to which South African firms disclose non-financial information in their annual report was studied using a quantitative methodology with extensive statistical modelling. In 2005, a sample of one hundred JSE-listed companies was selected. The sample was chosen from the Financial Mail's list of the top two hundred companies on the basis of their turnover (Financial Mail, 2005). In 2008, the same sample was used but it had in the meantime decreased to eighty-eight companies because fourteen had either been acquired or had merged with others in the sample. The 12 criteria discussed earlier in this article were used to analyse the annual reports for 2008 and compared to the results of 2005. As already mentioned, the first ten criteria (Table 1) had been used to evaluate strategy disclosure in Dutch annual reports and the additional two criteria were added as they were identified in 2005 as being very important for firms operating in the South African context (Santema and Van de Ritj, 2001; Padia and Yasseen, 2011).

The companies were rated for partial to full disclosure with scores ranging from 0 to 1 (Table 3 ). This data was collated on an Excel spreadsheet with the 100 companies along the left-hand side and the 12 variables along the right. To avoid any bias resulting from the subjective nature of the study, the author went through each set of financial statements and awarded scores for each company. It should be noted that scores were awarded for the extent of disclosure and not for quality. It was thus felt that, as the author was not assessing the relevance of the data, bias would be reduced. A score of zero denoted no disclosure and a score of one denoted maximum disclosure. The 2005 and 2008 annual reports were obtained either from McGregor BFA or directly from the 
Table 3. Scoring table - example of the HIV/AIDS criterion.

\begin{tabular}{cl}
\hline Score & \\
\hline 0 & $\begin{array}{l}\text { The company does not have an HIV/AIDS } \\
\text { strategy }\end{array}$ \\
0.25 & Some HIV/AIDS strategy is in place \\
0.5 & $\begin{array}{l}\text { The company has an adequate HIV/AIDS } \\
\text { strategy in place }\end{array}$ \\
0.75 & $\begin{array}{l}\text { There is a well-defined HIV/AIDS strategy } \\
1\end{array}$ \\
& $\begin{array}{l}\text { There is a comprehensive HIV/AIDS strategy in } \\
\text { place }\end{array}$ \\
\hline
\end{tabular}

respective company websites.

Each of the eighty-eight companies was inspected individually and an individual score was awarded for each item. The individual scores were then statistically analysed using the computer program STATA version 10. Some of the analysis carried out included the perce score, Cronbach's alpha for internal consistency and a twodimensional biplot of the dataset (Padia and Yasseen, 2011). Such a biplot simultaneously displays the observations (rows) and the relative positions of the variables (columns), while marker symbols (points) are displayed for observations and arrows are displayed for variables. These assisted in analysing the extent of disclosure and whether there was a significant correlation among the variables (Padia and Yasseen, 2011).

\section{RESULTS AND DISCUSSION}

A sample of one hundred JSE-listed companies and eighty-eight JSE-listed companies were used for the studies conducted in 2005 and in 2008 respectively and the sample was rated on the twelve variables selected. The companies were rated for partial to full disclosure with scores ranging from 0 to 1 (Table 3 ), with a score of zero denoting no disclosure and a score of one denoting maximum disclosure. The two samples were also analysed using the probability of a number between 0 and 1 describing the likelihood that a variable being analysed has been disclosed in the company's annual report.

The comparison of the results revealed that the mean overall disclosure percentage in 2005, based on 100 observations, was $60.4 \%$ (standard deviation $=29.4 \%$ ) with a median (and interquartile range) of $64.6 \%$ (37.5$89.6 \%$ ). The mean overall disclosure percentage in 2008 based on 88 observations was slightly higher at $62.2 \%$ (standard deviation $=26.5 \%$ ) with a median (and interquartile range) of $67.7 \%(45.8-82.3 \%)$. On average, the disclosure score in 2005 was similar to that in 2008, as reflected by a mean and median change of approximately -1 and $-2 \%$ respectively (standard deviation $=23.9 \%$; interquartile range: $-15.6 \%$ to $+13.5 \%$ ). The distribution of scores for 2005 and 2008, as well as the change in disclosure, can be seen in Figures 1 to 3 .

In 2005 , six companies (6\%) had maximum disclosure compared to three companies (3.4\%) in 2008. The relative distribution of disclosure scores by $20 \%$ intervals can be seen in Table 4. We observed fewer companies in the $80 \%$ + category in 2008 compared with 2005, but more in the 60 to $79 \%$ intervals in 2008 compared with 2005. This indicates that, contrary to expectation, fewer companies made full disclosure. This could be a result of the onset of the financial crisis, which might mean that companies were inclined to make less disclosure as a result.

Based on the Wilcoxon matched-pairs signed-ranks test, no significant change in paired rank occurred when comparing overall disclosure in 2005 with 2008 ( $z=$ $0.287 ; p=0.774)$. Similarly, when comparing actual disclosure score using a paired t-test, no significant difference in mean score was observed between these two time points $(t=0.32 ; p=0.750)$. Therefore, the overall change between 2005 and 2008 was not significant. This is interesting as one would expect that over a period of three years companies would either have improved their non-financial disclosure or, on the other hand, as a result of the financial crisis, would have decreased their disclosure quite significantly.

When comparing specific sub-category disclosure changes between these two time points, a highly significant increase in corporate strategy disclosure was observed $(z=-2.919 ; p=0.0035)$. A significant increase in business unit strategy also occurred $(z=-4.161 ; p<$ $0.001)$. Conversely, there was a significant decrease in monitoring disclosure between 2005 and $2008(z=2.544$; $p=0.0110)$. In addition, a marginally significant decrease in HIV disclosure was observed from 2005 to 2008 ( $z=$ $1.809 ; p=0.0704$ ). No other significant changes in temporal disclosure scores were observed in other specific sub-categories, that is, $p>0.1$ ).

We found a higher disclosure score to be significantly associated (correlated) with a higher FM ranking (that is, lower score), both in 2005 and in $2008(r=-0.78$ and 0.65 respectively, $p<0.05)$. A positive increase in overall disclosure was significantly (at $5 \%$ level) correlated with an FM ranking gain from 2005 to $2008(r=-0.22 ; p<$ 0.05 ). This indicates that more disclosure would have a positive effect on the companies' rankings, bearing in mind that this would not be the only factor to affect the ranking of a company. Figure 4 highlights this correlation.

The disclosure categories that were significantly, though weakly, correlated (as disclosure increased from 2005 to 2008 when see a gain in ranking) with an FM ranking gain appeared to be:

a) Corporate strategy disclosure $(r=-0.20 ; p<0.05)$; 
Table 4. Frequency of companies by overall disclosure score interval in 2005 and 2008.

\begin{tabular}{ccccc}
\hline Disclosure score interval (\%) & 2005 N & Percent (\%) & 2008 N & Percent (\%) \\
\hline $0-19$ & 11 & 11.0 & 8 & 9.1 \\
$20-39$ & 17 & 17.0 & 10 & 11.4 \\
$40-59$ & 16 & 16.0 & 17 & 19.3 \\
$60-79$ & 25 & 25.0 & 28 & 31.8 \\
$80-100$ & 31 & 31.0 & 25 & 28.4 \\
Total & 100 & 100.0 & 88 & 100.0 \\
\hline
\end{tabular}

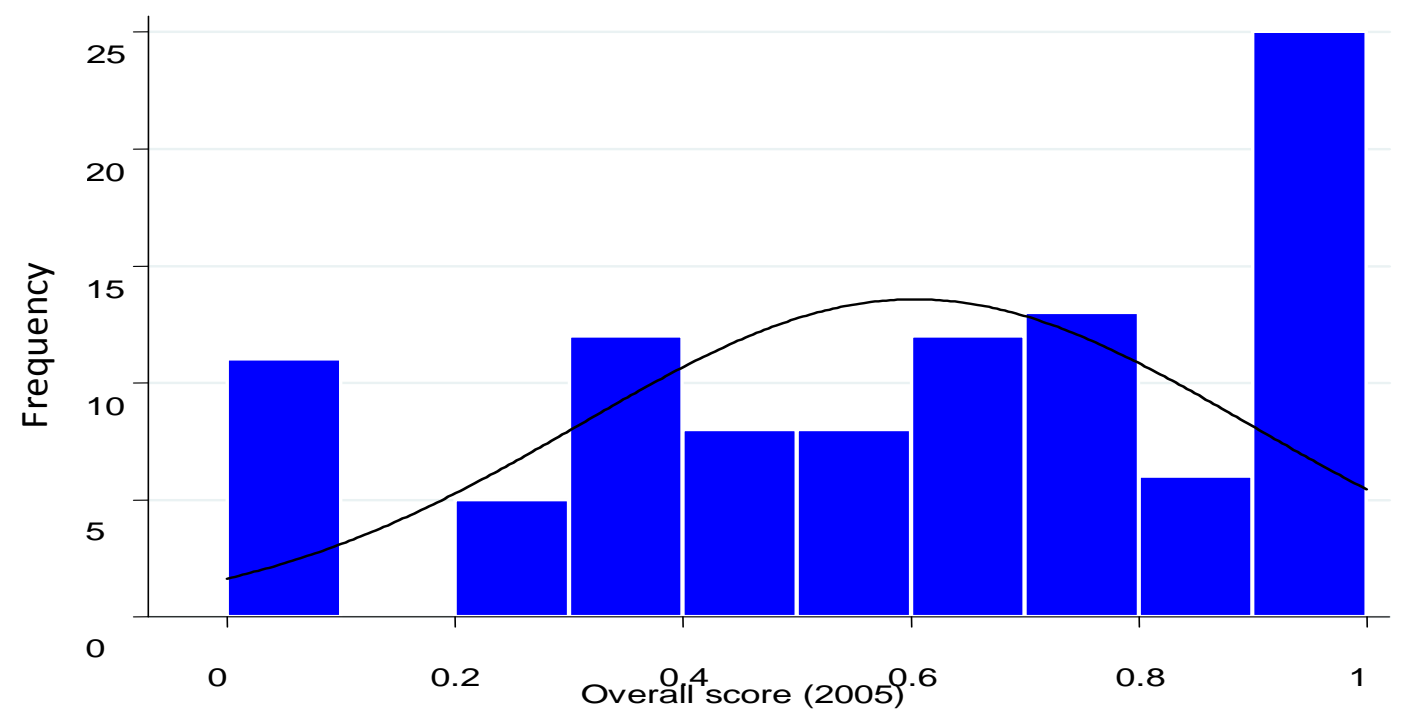

Figure 1. Histogram (with normal density plot) of overall disclosure score in 2005.

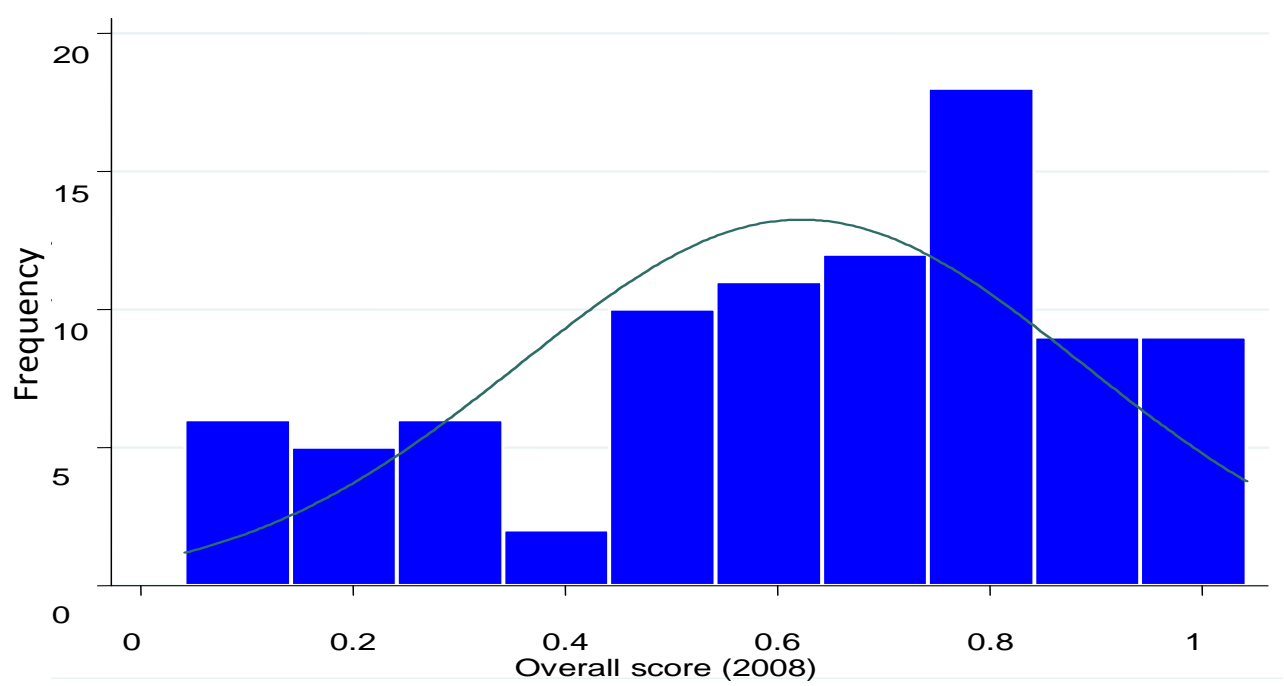

Figure 2. Histogram (with normal density plot) of overall disclosure fractions in 2008.

b) Monitoring disclosure $(r=-0.30 ; p<0.05)$;

c) Business unit strategy disclosure $(r=-0.31$; $p<0.05)$.
An increase in disclosure in the following appeared to be marginally correlated $(p>0.05$ and $<0.1)$ with a gain in 


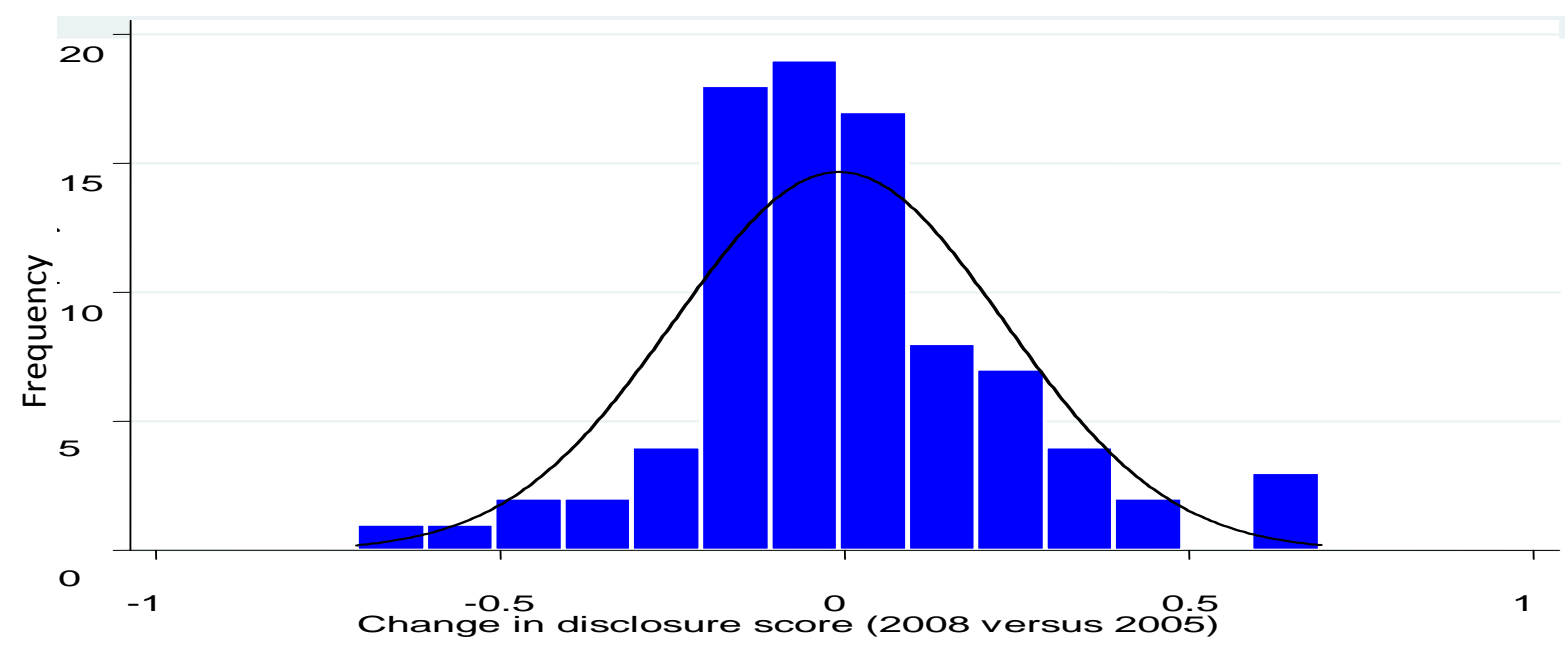

Figure 3. Histogram (with normal density plot) of overall disclosure fractional changes between 2005 and 2008.

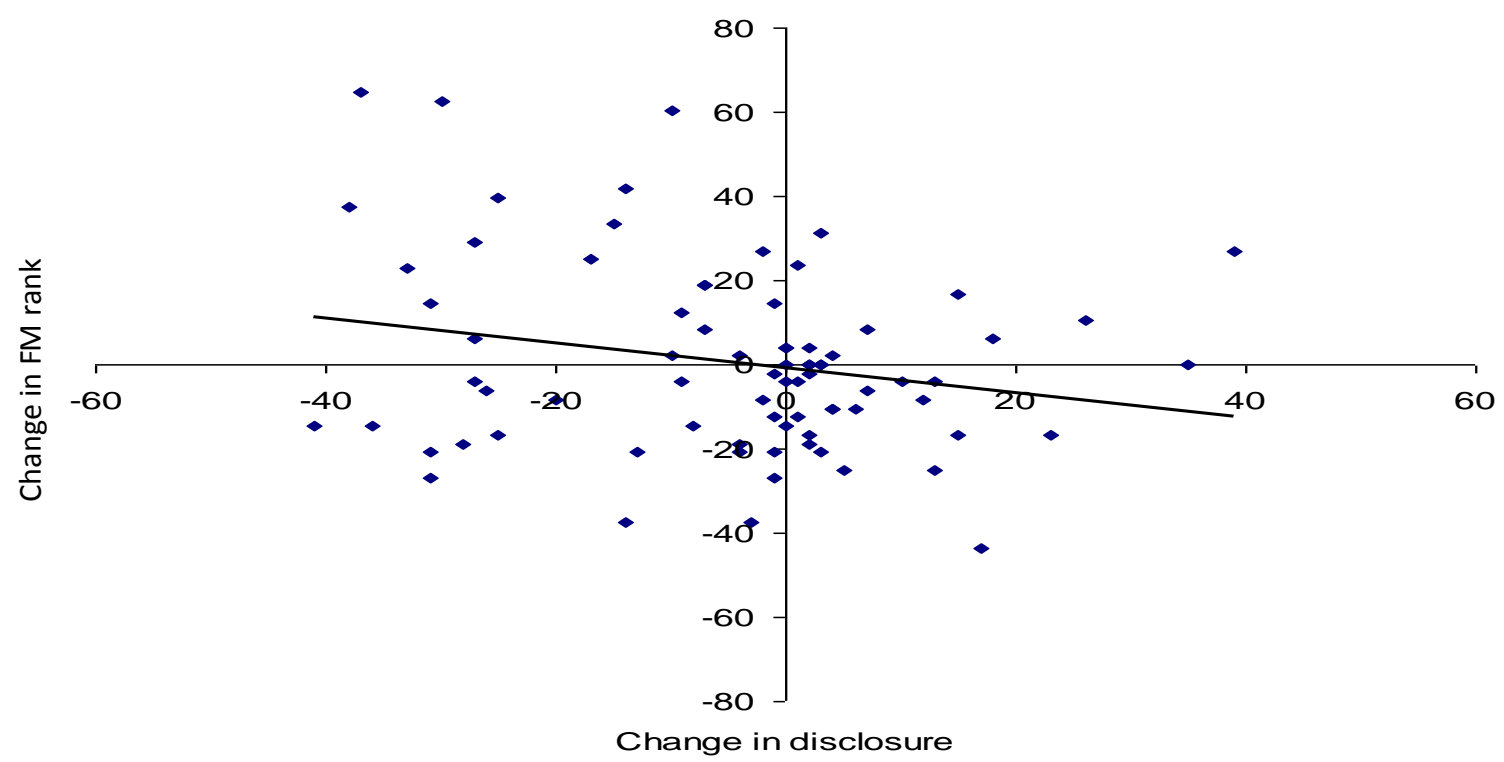

Figure 4. Scatter plot showing the correlation between a gain in FM rank (reflected by a negative value) and increasing disclosure from 2005 to 2008.

FM ranking from 2005 to 2008 :

a) Business unit goals disclosure $(r=-0.21)$;

b) Action plan (ex-ante) disclosure $(r=-0.22)$.

Padia and Yasseen's (2011) research examined the top 61 and the bottom 39 companies of the sample of 100 companies. Among the top 61 companies, six had $100 \%$ disclosure. In addition, 18 had a score of over $90 \%$, seven had a score greater than $80 \%$, and 12 had over $70 \%$ disclosure. This means that a total of 43 companies made more than $70 \%$ disclosure. In the bottom 39 companies, 11 companies scored less than $10 \%$ disclosure on the 12 variables.

The current study examined the top 52 and the bottom 36 of the eighty-eight JSE-listed companies selected in 2008. Among the top 52 were three companies with $100 \%$ disclosure; 10 companies that scored over $90 \%$; 10 companies that scored over $80 \%$; and 13 companies that scored over $70 \%$. This means that a total of 36 companies made over $70 \%$ disclosure. In the bottom 36 , only five companies made less than $10 \%$ disclosure on 
the 12 variables.

\section{Conclusion and limitations}

In 2005, the main finding of a study conducted by Padia and Yasseen (2011) indicated that the 12 strategy variables [10 of which were taken from a Dutch study by Santema and Van de Ritj (2001) and two additional variables deemed to reflect the South African context] used in the study can be grouped into categories. Most commonly, it was found that companies in South Africa pay more attention to describing the strategy variables of mission, objective and goals. Consequently, these three variables had the highest disclosure. Furthermore, over $40 \%$ of the companies scored a maximum score of 1 in this regard. What is important to note here is the fact that only $23 \%$ of the companies made very little or no disclosure. It is therefore encouraging to note that $73 \%$ of the companies made at least sufficient disclosure by scoring more than $50 \%$. These results can be compared with the Dutch study (Santema and Van De Ritj, 2001), where the variables of mission and objective did not score particularly high. In the Dutch study, objectives had a low score of $15 \%$ and variables such as action plans, ex-post and monitoring were more or less the same. In comparing the results obtained for 2005 and 2008, overall scores for both studies indicate a significant amount of disclosure in terms of corporate disclosure and business unit strategies disclosure in 2008. Greater disclosure also seems to be positively correlated with a higher Financial Mail ranking in the selected sample. On the other hand, the disclosure score of HIV/AIDS decreased from 2005 to 2008, and BEE disclosure also decreased substantially for the same period. This is interesting to note as one would expect that with increased focus on these two areas in South Africa there would have been an increase in disclosure for these two criteria.

Overall analysis of the 2008 findings indicates that $40 \%$ of the companies scored above $70 \%$ disclosure; three percent scored $100 \%$ disclosure, $11 \%$ scored above $90 \%, 11 \%$ scored above $80 \%$, and $15 \%$ scored above $70 \%$. Moreover, 10 companies had a score in excess of $90 \%, 10$ companies scored over $80 \%$, and 13 companies scored over $70 \%$. On the other hand, six percent of companies scored below $10 \%$, indicating little or no disclosure on the 12 variables.

Therefore, in $2005,70 \%$ of companies from the chosen sample scored above $70 \%$ on disclosure, whereas in $2008,69 \%$ of companies in the sample scored above $70 \%$. In 2005 , however, $28 \%$ of companies scored less than $10 \%$ on disclosure, while, by contrast in $2008,13 \%$ of companies scored less than $10 \%$. Therefore, the overall results indicate an increase in non-financial disclosure in the annual reports of JSE-listed companies from 2005 to 2008, although not significant, and greater disclosure was associated with a higher Financial Mail ranking (Figure 4) in 2008. A positive increase in overall disclosure was associated with a Financial Mail ranking gain in 2008. This means that JSE-listed companies should be encouraged to make non-financial disclosure pertaining to their strategy.

The main limitation of this study was that it evaluated the correlation between the amount of non-financial information disclosed in the annual reports of South African JSE-listed companies in 2005 and 2008, which is for a period of two years only. In addition, in 2005 the chosen sample included one hundred JSE-listed companies, whereas by 2008 the sample had decreased to eighty-eight, as twelve of the companies in the 2005 sample had been acquired by other companies, had merged with other companies in the sample or may have delisted. The King III report, which came into effect from 2010 , has created a huge potential for future research on non-financial disclosure.

\section{REFERENCES}

Aziz TA (2002). Reforming political governance: A business necessity. Ashgate Publications.

Baker S, Mezzetti C (2001). Disclosure as a strategy in the patent race.

Beattie V, Mclnnes B, Fearnley S (2004). A methodology for analysing and evaluating narratives in annual reports: A comprehensive descriptive profile and metrics for disclosure quality attributes. Account. Forum. 28:205-236.

Botosan C (1997). Disclosure level and the cost of equity. Account. Rev. 72:323-349.

Bowman E (1978). Strategy, annual reports, and alchemy. California Manage. Rev. 20:64-71.

Bukh P, Nielsen C, Gormsen P, Mouritsen J (2005). Disclosure of information on intellectual capital in Danish IPO prospectuses. Account. Aud. Accountab. J. 18:713-732.

Collett P, Hrasky S (2005). Voluntary disclosure of corporate governance practices by listed Australian companies. School of Account. Financ. 13(2):188-196.

Cheng ECM, Courtenay SM (2004). Board composition, regulatory regime and voluntary disclosure. Nanyang Business School.

Financial Mail (2005). SA giants: 200 Top performers. Financial Mail.

Francis J, Nanda D, Olsson P (2007). Voluntary disclosure, earnings quality, and cost of capital. Fuqua School of Business.

Gibbins M, Richardson A, Waterhouse J (1990). The management of corporate financial disclosure: opportunism, ritualism, and processes. J. Account. Res. 28(1):121-143.

Gray JS, Meek KG, Roberts BC (1995a). International capital market pressures and voluntary annual report disclosures by US and UK multinationals. J. Int. Financial. Manage. Account. 6(1):43-68.

Gray JS, Meek KG, Roberts BC (1995b). Factors influencing voluntary annual report disclosure by US, UK and continental European multinational corporations. J. Int. Bus. Stud. 26(3):555-572.

Healy P, Hutton A, Palepu K (1998). Stock performance and intermediation changes surrounding sustained increases in disclosure. Contemporary Accounting Research, forthcoming.

IOD (2009). King Code of Governance principles for South Africa 2009 - King Committee on Governance. Johannesburg: Institute of Directors Southern Africa.

Kohut G, Segars A (1992). The president's letter to stockholders: an examination of corporate communication strategy. J. Bus. Commun. 29(7). 
Luez C, Verrecchia RE (2000). The economic consequences of increased disclosure. J. Account. Res. 38:91-124.

Lang M, Lundholm R (1993). Cross-sectional determinants of analyst ratings of corporate disclosures. J. Account. Res. 31:246-271.

Lang MH, Lundholm RJ (1996). Corporate disclosure policy and analyst behaviour. Account. Rev. 71(4).

Miller PBW (1990). The conceptual framework as reformation and counter-reformation. Account. Horizons June, pp.23-32.

Padia N, Yasseen $Y$ (2011). An examination of strategy disclosure in the annual reports of South African listed companies. South Afri. J. Bus. Manage. 42(3):15-23.

Petersen C, Plenborg T (2006). Voluntary disclosure and information asymmetry in Denmark. J. Int. Account. Aud. Taxation 15:127-149.

Santema S, Hoekert M, Van de Rijt J, Van Oijen A (2005a). Strategy disclosure in annual reports across Europe: a study on differences between five countries. Europ. Bus. Rev. 17:352-366.

Santema S, Van de Ritj J, Van Oijen A (2005b). Strategy disclosure in annual reports across Europe: a study on differences between five countries. Eur. Bus. Rev. 17(4):352-366.
Santema S, Van de Ritj J (2001). Strategy disclosure in Dutch annual reports. Eur. Manag. J. 19:101-108.

Stanton P, Stanton J (2002). Corporate annual reports: research perspective used, Accounting. Aud. Account. J. 15(4):478-500.

Tasker SC (1998). Bridging the information gap: quarterly conference calls as a medium for voluntary disclosure. Rev. Account. Stud. 3:137-167.

Wallace RSO, Naser K (1995). Firm-specific determinants of the comprehensive of mandatory disclosure in the corporate annual reports of firms listed on the stock exchange of Hong Kong. J. Account. Public Policy 14:311-368. 